\title{
Dietary fatty acids affecting hepatic metabolism and atherosclerosis - mechanisms unravelled using a proteomics approach
}

\author{
By Guillermo Rodríguez Gutiérrez and Baukje de Roos*
}

\author{
Rowett Research Institute, Division of Vascular Health, Greenburn Road, Bucksburn, \\ Aberdeen AB21 9SB, United Kingdom \\ * Corresponding author: b.deroos@ rowett.ac.uk
}

\section{RESUMEN}

Los ácidos grasos de la dieta afectan al metabolismo hepático y la ateroesclerosis mecanismos no revelados usando una aproximación proteómica.

Los ácidos grasos de la dieta cumplen un importante papel en la etiología de las enfermedades coronarias. A pesar de estar bien descrito el efecto de dichos ácidos grasos sobre el metabolismo lipoproteíco, no se conocen mecanismos alternativos que relacionen su influencia sobre posibles enfermedades coronarias. En esta revisión se describe el uso de técnicas proteómicas para la identificación de proteínas diferencialmente reguladas por dichos ácidos grasos. Tales proteínas pueden revelar rutas metabólicas implicadas en el riesgo de enfermedades y reguladas por los ácidos grasos de la dieta.

PALABRAS CLAVE: Aceite de oliva virgen extra - Ácidos grasos de la dieta - Aterosclerosis - Metabolismo lipídico del hígado - Proteómica.

\section{SUMMARY}

Dietary fatty acids affecting hepatic metabolism and atherosclerosis - mechanisms unravelled using a proteomics approach.

Dietary fatty acids play an important role in the aetiology of coronary heart disease. The effects of dietary fatty acids on lipoprotein metabolism are well described, but additional or alternative mechanisms relating to potential influence on coronary heart disease are not known. This review describes how proteomics techniques have been used to identify proteins that are differentially regulated by dietary fatty acids. Such proteins may reveal pathways by which dietary fatty acids influence disease risk.

KEY-WORDS: Atherosclerosis - Dietary fatty acids Extra virgin olive oils - Hepatic lipid metabolism Proteomics.

\section{INTRODUCTION}

Over the last few years the complete human genome sequence has been determined (Lander et al., 2001). Despite the fact that this achievement is fundamental to our understanding of cellular metabolism, it does not show how the cell interacts with its external environment. Proteins can undergo posttranslational modifications resulting in multiple isoforms that may have different biological activities in cellular metabolism. These alterations may affect how well a form of the protein interacts with other proteins or substrates (Livingston et al., 2004). The complement of proteins in an organism as well as their interactions is defined as the proteome. The proteome is, unlike the genome, dynamic and varies according to the cell type and the functional state of the cell. Proteomics has the advantage over cDNA micro-arrays that it quantifies the functional product (protein) of gene expression, and in addition it allows the identification of protein modifications that may relate to the activation or inactivation of proteins by dietary interventions. Such proteins may not only play a major physiological role in a target organ for example, the liver but could also reflect changes in mechanisms initiated by dietary intervention when they are secreted into the circulation.

Currently, proteomic technologies use either specific digestion of proteins or direct analysis of intact proteins after their chromatographic separation. The multiple components of the proteome can be analysed by mass spectrometry (MS) after an evaporation of peptides and protein by electrospray ionisation (ESI) or matrix-assisted laser desorption ionisation (MALDI) technologies (Kim et al., 2004). Classical two-dimensional (2D) gel electrophoresis, where proteins are separated according to charge and molecular weight, coupled with protein spot analysis by mass spectrometry, is still the most widely used technical approach in proteomics to identify changes in individual proteins of tissues, cells and biofluids upon nutritional intervention (Kim et al., 2004; Fuchs et al., 2005). While this method is one of the most labourintensive of the several types of 2D separation methods available, it actually yields a physical separation of intact polypeptides from each other, providing information about molecular weight and iso-electric point. Such parameters can be used to narrow down the identification of the protein which can be further analysed by bioinformatics tools (Barnes and Kim, 2004).

The development of 'omics' (genomics, transcriptomics, proteomics and metabolomics) technologies in nutrition have opened new possibilities to elucidate the complex physiological 
effects of food components, nutrients, or a specific diet, which are often mediated through multiple biochemical and molecular mechanisms. Furthermore, knowledge about the actions of foods and nutrients on all possible physiological outcomes related to, for example, chronic disease development, is essential to identify dietary strategies that will promote health and delay the onset of chronic diseases. Within 'omics', proteomics holds great promise for nutrition research - proteins are ultimately involved in the absorption and distribution of nutrients, metabolism and excretion (Griffiths and Grant, 2006). Here we review studies of the effects of different dietary fatty acids on physiological outcome parameters and mechanistic pathways in the liver using proteomics. By applying a systems biology analysis we have identified novel mechanisms by which dietary fats and fatty acids affect proteins involved in processes related to coronary heart disease (CHD).

\section{DIETARY FATTY ACIDS, LIPOPROTEIN METABOLISM AND CORONARY HEART DISEASE}

The relationship between diet and $\mathrm{CHD}$, the major causes of morbidity and mortality in much of the world today (American Heart Association, 2008), has been studied intensively. Dietary fatty acids affect lipoprotein metabolism and their impact on CHD has traditionally been estimated from their effects on serum total cholesterol (Keys et al., 1957; Hegsted et al., 1965). Indeed, the type of fatty acid in a diet plays an important role in CHD prevention through beneficial or detrimental effect on the lipoprotein profile (Hu and Willett, 2002). For example, the Mediterranean diet has been associated with a lower risk of $\mathrm{CHD}$, because of its high content of monounsaturated fat, and because of a lower general fat intake than in other countries (Keys et al., 1986; de Lorgeril et al., 1999). Increased intake of diets rich in polyunsaturated fatty acids (PUFA) - like those containing a high fish content, have also been associated with a lower risk of CHD (Daviglus et al., 1997; Zhang et al., 1999). Consumption of saturated fatty acids and trans fatty acids, on the other hand, increase levels of lowdensity lipoprotein (LDL) and thereby also the risk of CHD (Mensink and Katan, 1992). Current recommendations include decreasing the intake of saturated and trans fats, and increasing the consumption of omega-3 fatty acids from fish, fish oil supplements and plant sources as a part of a hearthealthy diet (Krauss et al., 2000). However, many issues relating to the intake of dietary fatty acids other then their effects on lipoprotein metabolism remain unresolved.

\section{EXTRA VIRGIN OLIVE OILS AND ATHEROSCLEROSIS}

Mediterranean populations generally consume a diet high in extra virgin olive oils (EVOO) that are rich in monounsaturated fatty acids (MUFA) and minor antioxidant constituents, mainly phenolic compounds, which may contribute to a lower risk of CHD (Ferro-Luzzi and Branca, 1995; Visioli and Galli, 2002). We have applied a systems biology approach to gain understanding in mechanisms by which Picual and Arbequina EVOO may affect hepatic metabolic pathways, oxidative stress and eventually atherogenesis (Arbones-Mainar et al., 2007). Both Picual and Arbequina EVOO decreased atherosclerotic plaque size after 10 weeks of intervention in $A p o e^{-/}$mice, a model of atherosclerosis. Both forms of EVOOs also induced the accumulation of triglycerides in the liver, without apparent changes in levels of hepatic $\beta$-oxidation, resulting in an increased hepatic fat content and liver weight (Arbones-Mainar et al., 2007). These results imply that olive oils can, on the one hand, reduce the risk of atherosclerotic plaque formation, but can also increase the risk of hepatic steatosis. A systems biology approach was crucial in unravelling these complex interactions. Using proteomics we revealed a significant up-regulation of a large array of antioxidant enzymes in the liver after consumption of extra virgin olive oils (Table 1). Such

Table 1

Differential regulation of hepatic anti-oxidant enzymes, identified through proteomics, upon consumption of dietary Picual or Arbequina extra virgin olive $(20 \% \mathrm{w} / \mathrm{w})$ for 10 weeks in $A p o e^{-/}$mice.

\begin{tabular}{lcc}
\hline \multicolumn{1}{c}{ Antioxidant Enzyme } & Picual olive oil & Arbequina olive oil \\
\hline Thioredoxin Reductase & $+200 \%$ \\
\hline Thioredoxin peroxidase 2 & $+200 \%$ & $+250 \%$ \\
\hline Peroxiredoxin 3 & $+150 \%$ \\
\hline Superoxide dismutase & $+250 \%$ \\
\hline Glutathione peroxidase 1 & $-20 \%$ \\
\hline Glutathione synthase & $+230 \%$ \\
\hline Glutathione S-transferase & $+190 \%$ & $+190 \%$ \\
\hline
\end{tabular}

Values represent \% up- or downregulation as compared with the dietary palm oil control $(20 \% \mathrm{w} / \mathrm{w})$ 
an upregulation could diminish oxidative stress instigated by hepatic steatosis and thus slow down the development of atherosclerosis. Therefore compounds in extra virgin olive oils (such as the polyphenols) may well be able to delay the onset of atherosclerotic lesions by preventing excessive oxidative stress. Indeed, the accumulation of triglycerides may not pose a major challenge to the liver, and represent a relatively safe way to store triglycerides, as long as the antioxidant capacity is adequate to prevent lipotoxicity (Arbones-Mainar et al., 2007).

\section{DIFFERENTIAL REGULATION OF TWO DIETARY CONJUGATED LINOLEIC ACID ISOMERS}

Conjugated linoleic acids (CLA) are a group of conjugated dieonic isomers of linoleic acid belonging to ruminant-derived trans fatty acids. They are present as minor constituents of the lipid fraction of meat, milk, and dairy products as well as other foods derived from ruminant animals. CLA can protect against the development of atherosclerosis in rabbits (Kritchevsky et al., 2000; Lee et al., 1994), hamsters (McLeod et al., 2004; Nicolosi et al., 1997; Wilson et al., 2000) and transgenic mice (Toomey et al., 2003). The mechanisms for this are not well understood, but might involve modification of the production of atherogenic lipoproteins by the liver or modification of inflammatory pathways.

We found that two CLA isomers - almost structurally identical - had divergent mechanistic effects on atherosclerosis development and insulin resistance in $A p o e^{-/}$mice. Consumption of trans 10 , cis12 CLA, a fatty acid present in many supplements that are currently freely available, was pro-atherogenic and induced pathways involved in the development of insulin resistance. This was evident from simultaneous changes in enzymes involved in gluconeogenesis, lipid degradation and ketone body formation (de Roos et al., 2005b). In addition, consumption of the cis 9,trans 11 isomer of CLA resulted in an antidiabetic effect, decreased protein levels of proinflammatory macrophage migration inhibitory factor, and increased expression of antiinflammatory HSP $70 \mathrm{kD}$ in liver (de Roos et al., $2005 b$ ). Although one may consider the latter to be an indication of increased oxidative stress, we have postulated that up-regulation of HSP $70 \mathrm{kD}$ protein upon exposure to a relatively mild stress stimulus (like cis9, trans11 CLA) could protect against exposure to more severe stress. For example, those related to anti-inflammatory pathways (mediated through NF-кB) (Shimizu et al., 2002). Indeed, increased levels of human serum HSP 70 have been associated with a low coronary artery disease risk, independent of traditional risk factors (Zhu et al., 2003).

\section{DIETARY FATTY ACIDS AND THE HEPATIC PROTEOME: FISH OIL, TRANS-10, CIS-12 CLA, AND ELAIDIC ACID}

How various dietary fatty acids can differentially affect hepatic protein expression became clear when we compared the effects of three dietary fatty acids - fish oil, trans10, cis12 CLA and elaidic acid - on plasma and liver metabolites and hepatic proteins in ApoE*3-Leiden transgenic mice (de Roos et al., 2005a). These mice are a model for lipid metabolism, insulin resistance and atherosclerosis that are sensitive to changes in many components of the diet (van Vlijmen et al., 1994; van Vlijmen et al., 1996; van Vlijmen et al., 1998). Proteomics of diet-induced changes revealed a wide array of hepatic proteins that were affected by the three dietary fatty interventions. Significant changes were detected in pathways involved with glucose and lipid metabolism. This was consistent with the physiological changes that occurred in response to the diets. For example, fish oil, and also trans10, cis12 CLA, increased hepatic catalase and long chain acyl-CoA thioester hydrolase proteins, indicative of an increased $\beta$ oxidation rate (de Roos et al., 2005a). Long chain acyl-CoA thioester hydrolase expression had never been linked to specific dietary fatty acid treatments before. The suspected increase in $\beta$-oxidation rates would explain the lower levels of plasma triglycerides and free fatty acids as well as hepatic triglycerides in the mice after fish oil consumption. The increase in $\beta$-oxidation caused by trans 10 , cis12 CLA consumption was however indicative of the development of insulin resistance, since levels of plasma and hepatic triglycerides, as well as plasma $\beta$-hydroxybutyrate and plasma insulin were significantly increased (de Roos et al., 2005a).

The decrease in hepatic lipid levels in the animals consuming fish oil and the significant increase in hepatic triglyceride levels in the trans 10 , cis 12 CLA group matched with corresponding significant decreases or increases in levels of hepatic adipophilin. Adipophilin is associated with lipid storage droplets that function as deposits for triglycerides and cholesterol esters (McManaman et al., 2003). Increased expression of adipophilin has been associated with liver steatosis (Heid et al., 1998), and CLA-mediated liver steatosis has occurred in different strains of mice (Clement et al., 2002; Degrace et al., 2003). Liver steatosis is often associated with obesity, diabetes, hyperinsulinemia and VLDL overproduction (den Boer et al., 2004), and we saw some, but not all, of these associations in our trans10, cis12 CLA fed mice (de Roos et al., 2005a).

\section{DIETARY FISH OIL: EFFECTS ON THE PLASMA PROTEOME}

Dietary intervention may cause changes in proteins that are secreted into the blood. A major benefit of the proteomics platform is the non-invasive 
analysis of human body fluids to determine the consequences of such nutritional interventions. For example, proteomics studies have the potential to identify biomarkers for health, to reveal early indications for disease disposition, assist in differentiating dietary responders from non-responders, and to discover beneficial food components (Kussmann et al., 2006). We have assessed the effects of dietary fish oil supplementation for six weeks on the serum proteome of healthy subjects. Fish oil, compared with high oleic sunflower oil supplementation, significantly down-regulated serum apolipoprotein A1, apolipoprotein L1, zinc- $\alpha-2$-glycoprotein, haptoglobin precursor, $\alpha$-1-antitrypsin precursor, anti-thrombin IIIlike protein, serum amyloid $\mathrm{P}$ component, and haemopexin. In addition, the decrease in serum apolipoprotein A1 was associated with a significant shift towards the larger, more cholesterol-rich $\mathrm{HDL}_{2}$ particles. The alterations in serum proteins and HDL size imply that fish oil activates anti-inflammatory and lipid modulating mechanisms believed to impede the early-onset of CHD. These proteins are potential diagnostic biomarkers to examine the mechanisms whereby fish oils protect against CHD in humans (de Roos et al., 2008).

\section{CONCLUSIONS}

Proteomics is an emerging and promising tool to discover the mechanisms of action of nutrients allied to the identification of new biomarkers of health or disease. In particular the combination of proteomics data with physiological parameters, using correlation analysis as a statistical tool, will help to understand how dietary components regulate several metabolic processes (de Roos et al., 2005a; de Roos et al., 2005b; Arbones-Mainar et al., 2007; Milner, 2007). Current proteomics approaches in nutrition research mainly include the use of protein separation, visualisation and identification by 2D gel electrophoresis combined with mass spectrometry (Fuchs et al., 2005). Despite its limited ability to detect regulation of low abundant proteins, this approach has already provided valuable insights in the effects of several dietary interventions on (relatively abundant) proteins involved in the regulation of glucose and fatty acid metabolism, oxidative stress, and the redox regulation. The ability to measure the regulation of more low abundance proteins, such as those involved in inflammatory pathways, as well as the evaluation and validation of newly discovered candidate biomarkers in human biofluids, may depend on the introduction of more quantitative and sensitive methods like multiple reaction monitoring (MRM) and multiplexed immunoassays.

\section{ACKNOWLEDGEMENTS}

The authors' work is funded by the Scottish Government Rural and Environment Research and
Analysis Directorate (RERAD). The authors wish to thank to Ministerio de Educación y Ciencia (Spain) for the fellowship (2007-0954) granted to GRG.

\section{REFERENCES}

American Heart Association. 2008. Heart and Stroke Statistical Update. http://www.americanheart.org.

Arbones-Mainar JM, Ross K, Rucklidge GJ, Reid M, Duncan G, Arthur JR, Horgan GW, Navarro MA, Carnicer R, Arnal C, Osada J, Roos BD. 2007. Extra Virgin Olive Oils Increase Hepatic Fat Accumulation and Hepatic Antioxidant Protein Levels in APOE(-/-) Mice. J. Proteome. Res. 6, 4041-4054.

Barnes S, Kim H. 2004. Nutriproteomics: identifying the molecular targets of nutritive and non-nutritive components of the diet. J. Biochem. Mol .Biol. 37, 5974.

Clement L, Poirier H, Niot I, Bocher V, Guerre-Millo M, Krief S, Staels B, Besnard P. 2002. Dietary trans-10,cis-12 conjugated linoleic acid induces hyperinsulinemia and fatty liver in the mouse. J .Lipid Res. 43, 1400-1409.

Daviglus ML, Stamler J, Orencia AJ, Dyer AR, Liu K, Greenland P, Walsh MK, Morris D, Shekelle RB. 1997. Fish consumption and the 30-year risk of fatal myocardial infarction. N. Engl. J. Med. 336, 10461053.

de Lorgeril M, Salen P, Martin JL, Monjaud I, Delaye J, Mamelle N. 1999. Mediterranean diet, traditional risk factors, and the rate of cardiovascular complications after myocardial infarction: final report of the Lyon Diet Heart Study. Circulation 99, 779-785.

de Roos B, Duivenvoorden I, Rucklidge G, Reid M, Ross K, Lamers RJ, Voshol PJ, Havekes LM, Teusink B. 2005a. Response of apolipoprotein $E^{\star} 3$-Leiden transgenic mice to dietary fatty acids: combining liver proteomics with physiological data. FASEB J 19, 813815.

de Roos B, Geelen A, Ross K, Rucklidge G, Reid M, Duncan G, Caslake M, Horgan G, Brouwer IA. 2008. Identification of potential serum biomarkers of inflammation and lipid modulation that are altered by fish oil supplementation in healthy volunteers. Proteomics 8, 1965-1974.

de Roos B, Rucklidge G, Reid M, Ross K, Duncan G, Navarro MA, Arbones-Mainar JM, Guzman-Garcia MA, Osada J, Browne J, Loscher CE, Roche HM. 2005b. Divergent mechanisms of cis9, trans11-and trans10, cis12-conjugated linoleic acid affecting insulin resistance and inflammation in apolipoprotein E knockout mice: a proteomics approach. FASEB $J$ 19, 1746-1748.

Degrace P, Demizieux L, Gresti J, Chardigny JM, Sebedio JL, Clouet P. 2003. Association of liver steatosis with lipid oversecretion and hypotriglyceridaemia in C57BL/6j mice fed trans-10,cis-12-linoleic acid. FEBS Lett 546, 335-339.

den Boer M, Voshol PJ, Kuipers F, Havekes LM, Romijn JA. 2004. Hepatic steatosis: a mediator of the metabolic syndrome. Lessons from animal models. Arterioscler Thromb. Vasc. Biol. 24, 644-649.

Ferro-Luzzi A,Branca F. 1995. Mediterranean diet, Italianstyle: prototype of a healthy diet. Am. J. Clin. Nutr. 61, 1338S-1345S.

Fuchs D, Winkelmann I, Johnson IT, Mariman E, Wenzel $\mathrm{U}$, Daniel H. 2005. Proteomics in nutrition research: 
principles, technologies and applications. Br. J. Nutr. 94, 302-314.

Griffiths HR,Grant MM. 2006. The use of proteomic techniques to explore the holistic effects of nutrients in vivo. Nutr. Research. Rev. 19, 284-293.

Hegsted DM, McGandy RB, Myers ML, Stare FJ. 1965. Quantitative effects of dietary fat on serum cholesterol in man. Am. J .Clin .Nutr. 17, 281-295.

Heid HW, Moll R, Schwetlick I, Rackwitz HR, Keenan TW. 1998. Adipophilin is a specific marker of lipid accumulation in diverse cell types and diseases. Cell Tissue Res. 294, 309-321.

Hu FB, Willett WC. 2002. Optimal diets for prevention of coronary heart disease. JAMA 288, 2569-2578.

Keys A, Anderson JT, Grande F. 1957. Prediction of serum-cholesterol responses of man to changes in fats in the diet. Lancet 273, 959-966.

Keys A, Menotti A, Karvonen MJ, Aravanis C, Blackburn $\mathrm{H}$, Buzina R, Djordjevic BS, Dontas AS, Fidanza F, Keys $\mathrm{MH}$, . 1986. The diet and 15-year death rate in the seven countries study. Am. J. Epidemiol 124, 903915.

Kim H, Page GP, Barnes S. 2004. Proteomics and mass spectrometry in nutrition research. Nutrition 20, 155165.

Krauss RM, Eckel RH, Howard B, Appel LJ, Daniels SR, Deckelbaum RJ, Erdman JW, Jr., Kris-Etherton P, Goldberg IJ, Kotchen TA, Lichtenstein AH, Mitch WE, Mullis R, Robinson K, Wylie-Rosett J, St Jeor S, Suttie J, Tribble DL, Bazzarre TL. 2000. AHA Dietary Guidelines: revision 2000: A statement for healthcare professionals from the Nutrition Committee of the American Heart Association. Circulation 102, 22842299.

Kritchevsky D, Tepper SA, Wright S, Tso P, Czarnecki SK. 2000. Influence of conjugated linoleic acid (CLA) on establishment and progression of atherosclerosis in rabbits. J. Am. Coll. Nutr. 19, 472S-477S.

Kussmann M, Raymond F, Affolter M. 2006. OMICSdriven biomarker discovery in nutrition and health. $J$. Biotechnol 124, 758-787.

Lander ES, Linton LM, Birren B, Nusbaum C, Zody MC, Baldwin J, et al. 2001. Initial sequencing and analysis of the human genome. Nature 409, 860-921.

Lee KN, Kritchevsky D, Pariza MW. 1994. Conjugated linoleic acid and atherosclerosis in rabbits. Atherosclerosis 108, 19-25.

Livingston RJ, von Niederhausern A, Jegga AG, Crawford DC, Carlson CS, Rieder MJ, Gowrisankar S, Aronow BJ, Weiss RB, Nickerson DA. 2004. Pattern of sequence variation across 213 environmental response genes. Genome Res. 14, 1821-1831.

McLeod RS, LeBlanc AM, Langille MA, Mitchell PL, Currie DL. 2004. Conjugated linoleic acids, atherosclerosis, and hepatic very-low-density lipoprotein metabolism. Am. J. Clin. Nutr. 79, 1169S1174 S.

McManaman JL, Zabaronick W, Schaack J, Orlicky DJ. 2003. Lipid droplet targeting domains of adipophilin. J. Lipid Res. 44, 668-673.
Mensink RP,Katan MB. 1992. Effect of dietary fatty acids on serum lipids and lipoproteins. A meta-analysis of 27 trials. Arterioscler Thromb. 12, 911-919.

Milner JA. 2007. Nutrition in the 'omics' era. Forum Nutr. $60,1-24$.

Nicolosi RJ, Rogers EJ, Kritchevsky D, Scimeca JA, Huth PJ. 1997. Dietary conjugated linoleic acid reduces plasma lipoproteins and early aortic atherosclerosis in hypercholesterolemic hamsters. Artery 22, 266-277.

Shimizu M, Tamamori-Adachi M, Arai H, Tabuchi N, Tanaka H, Sunamori M. 2002. Lipopolysaccharide pretreatment attenuates myocardial infarct size: A possible mechanism involving heat shock protein 70inhibitory kappaBalpha complex and attenuation of nuclear factor kappa B. J. Thorac. Cardiovasc. Surg. 124, 933-941.

Toomey S, Roche H, Fitzgerald D, Belton O. 2003. Regression of pre-established atherosclerosis in the apoE-/- mouse by conjugated linoleic acid. Biochem . Soc. Trans. 31, 1075-1079.

van Vlijmen BJ, Mensink RP, 't Hof HB, Offermans RF, Hofker MH, Havekes LM. 1998. Effects of dietary fish oil on serum lipids and VLDL kinetics in hyperlipidemic apolipoprotein $E^{\star} 3$-Leiden transgenic mice. J. Lipid Res. 39, 1181-1188.

van Vlijmen $\mathrm{BJ}$, van 't $\mathrm{Hof} \mathrm{HB}, \mathrm{Mol} \mathrm{MJ}$, van der Boom $\mathrm{H}$, van der Zee A, Frants RR, Hofker MH, Havekes LM. 1996. Modulation of very low density lipoprotein production and clearance contributes to age- and gender- dependent hyperlipoproteinemia in apolipoprotein E3-Leiden transgenic mice. J. Clin. Invest. 97, 1184-1192.

van Vlijmen BJ, van den Maagdenberg AM, Gijbels MJ, van der Boom $\mathrm{H}$, HogenEsch $\mathrm{H}$, Frants RR, Hofker $\mathrm{MH}$, Havekes LM. 1994. Diet -induced hyperlipoproteinemia and atherosclerosis in apolipoprotein E3-Leiden transgenic mice. J. Clin. Invest. 93, 1403-1410.

Visioli F,Galli C. 2002. Biological properties of olive oil phytochemicals. Crit. Rev. Food Sci. Nutr. 42, 209221.

Wilson TA, Nicolosi RJ, Chrysam M, Kritchevsky D. 2000. Conjugated linoleic acid reduces early aortic atherosclerosis greater than linoleic acid in hypercholesterolaemic hamsters. Nutr. Res. 20, 17951805.

Zhang J, Sasaki S, Amano K, Kesteloot H. 1999. Fish consumption and mortality from all causes, ischemic heart disease, and stroke: an ecological study. Prev. Med. 28, 520-529.

Zhu J, Quyyumi AA, Wu H, Csako G, Rott D, ZallesGanley A, Ogunmakinwa J, Halcox J, Epstein SE. 2003. Increased serum levels of heat shock protein 70 are associated with low risk of coronary artery disease. Arterioscler. Thromb. Vasc. Biol. 23, 10551059. 